\title{
A Quantitative Study of the Fauna of the Sandy Beach at Port Erin.
}

\author{
By
}

Marjorie E. Pirrie, B.Sc.,

J. R. Bruce, M.Sc.,

and

H. B. Moore, B.Sc.,

From the Marine Biological Station, Port Erin.

With 8 Figures in the Text.

\section{Contents}

Introductory . . . . . . . . . . . . . . . . 279

Description of the Area . . . . . . . . . . . . 280

Stations . . . . . . . . . . . . . . 281

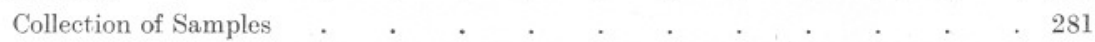

METHODS AND RESULTS

A. Chemical and Physical :

Hydrogen-ion concentration. . . . . . . . . 282

Salinity . . . . . . . . . . . . . . . 284

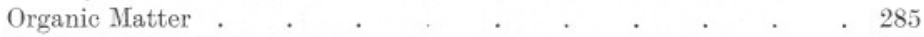

Mechanical Analysis . $\quad . \quad$. $\quad$. $\quad$. $\quad$. $\quad$. $\quad . \quad 285$

B. Biological :

Table of Occurrence of the Species . . . . . . . 288

Notes on the Species . . . . . . . . 287

GENERAL REMARKS . . . . . . . . . . . . . . . . . . . 291

SUMNARY . . . . . . . . . . . . . . . . . . . . . . . 295

REFERENCES . . . . . . . . . . . . . . . . . . . . . . 295

\section{INTRODUCTORY.}

In previous papers from this Station, one of us (Bruce, 2 and 3 ) has attempted to define certain of the physical and chemical influences which affect the animal and plant life of the sandy beach. The present paper embodies the results of an intensive faunistic survey of the sandy beach at Port Erin, Isle of Man, carried out in September, 1931, and seeks to correlate the observed distribution of the macro-fauna with the range of physical conditions already established and amplified in the course of the present work. 
Such a study enables a comparison to be made with the results of similarly conceived surveys on Scottish shores recently carried out by Stephen $(\mathbf{7}, \mathbf{8})$ and Elmhirst (5). Marked differences of faunal distribution are evident, as between the various localities. Many of the Scottish beaches examined by Stephen were comparatively sheltered, and harboured a very large molluscan population. The beach at Port Erin is subject to much disturbance by westerly storms, and is, on the whole, of coarser grade-in consonance with these conditions, molluses are practically absent, while polychætes and crustaceans compare favourably in density of population, but not in number of species, with most of the Scottish stations examined.

\section{Description of the Area.}

Port Erin Bay, near the south-west extremity of the Isle of Man, is more or less rectangular in outline, about half a mile wide, and open to the west. It is sheltered, on the north, by the bold cliffs and slopes of Bradda Head, which rise steeply to a height of 350 feet. On the east is the lower ground on which the village of Port Erin is built, and this terminates on the shore in steep bluffs or "brooghs" of glacial drift. From High-Water Mark at the foot of the brooghs, a wide stretch of smooth sand extends seawards for at least 500 feet at Low-Water Springs, and this constitutes the immediate area (Fig. 1, p. 283) of our survey. On the south of the bay are low cliffs, composed, like Bradda Head, of "Barrule Slates " of supposedly Cambrian age.

Although the bay is open to the west, some measure of protection is afforded on that side by a ruined breakwater, but this is covered at HighWater Neaps, and in any case extends only across the southern half of the opening. East of the breakwater, and at the south end of the sandy beach, a short half-tide pier, and a length of quay-wall, both directed to the north-east, give rise to a small protected area of beach with the usual harbour characteristics of finer grade, rich accumulation of detritus, and blackening below the surface. Apart from this area, the sand of the beach is clean, and of moderately fine grade. In general, there is a definite increase in the proportion of coarse material, up to $2 \mathrm{~mm}$. diameter, towards H.W.M., and more particularly towards the north end of the beach, where denudation has almost entirely removed the finer materials, leaving an area of coarse gravel with pebbles (Fig. 3, p. 290). The observed distribution of the beach-deposits is due, in part to the flood-current which enters the bay from the north-west, and in part to the harbourworks, which arrest the materials carried by the clockwise eddy in the bay. The slope of the beach, in the southern and middle portion, is fairly uniform, about 1 in 40, but in the northern part (lines D and E on Plan, 
Fig. 1) the section is markedly concave, flattened below Mean Sea Level, and steep above it. There are, of course, local depressions and banks which modify the general section, and the whole contour is liable to alteration as a result of winter storms.

The beach is traversed by several streamlets of fresh water, as shown in Figure 1, but the extent and influence of this factor is discussed under "salinity," p. 284, and on p. 292.

\section{Stations.}

For the purpose of sampling the fauna, and determining the physical character of the ground, in as representative a manner as possible, five lines, or "transects," were set out, more or less radial to the curve of the beach, and upon each line five observation-stations were plotted, at successive tidal levels, from Low-Water Equinoctial Springs to HighWater Neaps (Fig. 1). In addition to these twenty-four stations (one being common to two lines), two others, designated "I.H. " and " O.H." on the plan, are representative of the conditions in the inner and outer harbour respectively, while a third, " $\mathrm{R}$," is in an area partly sheltered by outcropping rocks at the extreme north end of the sandy beach.

The positions of all stations were determined by direct measurement or by prismatic compass-bearings, and accurately laid down on the 25 -in. Ordnance Sheet, Isle of Man, XV, 12. Accurate levels were taken at all stations, and referred to the nearest Ordnance Bench Mark (Table 1). The interpolation of tidal contours (Fig. 1) between the stations was facilitated, in some cases, by actually plotting the position of the water's edge.

\section{TABLE 1.}

Levels at Stations on Port Erin Beach.

\begin{tabular}{|c|c|c|c|c|c|}
\hline \multirow[b]{2}{*}{ Station } & \multicolumn{4}{|c|}{ (Heights in feet above Ordnance Datum.*) } & \multirow{2}{*}{ E } \\
\hline & A & B & $\mathrm{C}$ & D & \\
\hline 1. & & & $-9 \cdot 00$ & $-9 \cdot 00$ & $-9 \cdot 00$ \\
\hline 2. & $-4 \cdot 78$ & $-6 \cdot 61$ & $-6 \cdot 63$ & $-7 \cdot 50$ & $-7 \cdot 10$ \\
\hline 3. & -0.04 & -1.92 & $-0 \cdot 82$ & $-2 \cdot 64$ & -2.98 \\
\hline 4. & $2 \cdot 96$ & $3 \cdot 47$ & $2 \cdot 70$ & $3 \cdot 05$ & 1.82 \\
\hline 5 . & $6 \cdot 60$ & $6 \cdot 54$ & $7 \cdot 08$ & $7 \cdot 06$ & $4 \cdot 87$ \\
\hline & I.H. & O.H. & $-5 \cdot 80$ & $-2 \cdot 36$ & \\
\hline
\end{tabular}

\section{Collection of Samples.}

The area covered by each sample-a quarter of a square metre-is that commonly accepted in ecological work, and used by Stephen and Elmhirst (loc. cit.) in their surveys of Scottish beaches.

A wire frame, $50 \times 50 \mathrm{~cm}$., was used to define the area, and the sand, dug out as quickly as possible to within a short distance of the frame,

* Ordnance Datum in the Isle of Man is Mean Sea Level at Douglas. 
and to a depth of about $20 \mathrm{~cm}$., was transferred to a large galvanised bath-tub. At almost every station, two such samples were dug, and in a few important areas, three. The contents of the bath-tub were sieved through a $2-\mathrm{mm}$. sieve with circular holes, which was plunged up and down in the sea, the material retained by the sieve being set aside for later examination.

Various contingencies, such as flooding, or collapse of the hole, combined to render precision impossible, but after a little experience, allowance could be made for these, so that a fair uniformity of sampling was attained.

In addition to the large sample, a small tin, holding about 1 litre, was filled and closed with an airtight lid, for chemical tests and mechanical analysis of the finer material. This sample was taken at about the middepth of the hole.

\section{METHODS AND RESULTS.}

\section{A. Chemical and Physical.}

The chemical tests were carried out as soon as possible-sometimes within an hour, always within two hours-after the collection of the sample.

Hydrogen-ion concentration. The sand had usually settled sufficiently in its tightly sealed tin to permit of the necessary 10 c.c. being pipetted off. Where this was not possible owing to the dryness of the sample, the sand was transferred to a Buchner funnel, and sufficient water removed by slight suction. It was shown that, provided the suction was slight and not long-continued, no appreciable change in $\mathrm{pH}$ resulted from this treatment, owing doubtless to the high excess-base content and buffer-capacity of the interstitial water. Cresol red and m-Cresol purple were found to cover the range of $\mathrm{pH}$ observed; comparison was made with a series of Clark and Lubs standard buffer-mixtures, in a suitably screened rack, and a correction for salt-error, varying with the salinity of the sample, was applied to the reading, the result being stated to the nearest $0.05 \mathrm{pH}$ (Table 2).

TABLE 2.

pH of the Interstitial Water on the Sandy Beach at Port Erin-September.

(Values are corrected for salt-error.)

$\begin{array}{ccccccc}\text { Station } & \text { A } & & \text { B } & \text { C } & \text { D } & \text { E } \\ \text { l. } & & 7.85 & & - & 7.60 & 7.80 \\ 2 . & 7.95 & & 7.95 & 7.95 & 7.95 & 7.95 \\ 3 . & 7.85 & & 7.95 & 7.85 & 7.80 & 7.90 \\ 4 . & 7.95 & & 7.95 & 7.90 & 7.85 & 7.80 \\ 5 . & - & & 7.95 & \text { (dry) } & \text { (dry) } & \text { (dry) }\end{array}$

I.H. $8 \cdot 20$; O.H. $8 \cdot 25$; R. $7 \cdot 80$ 


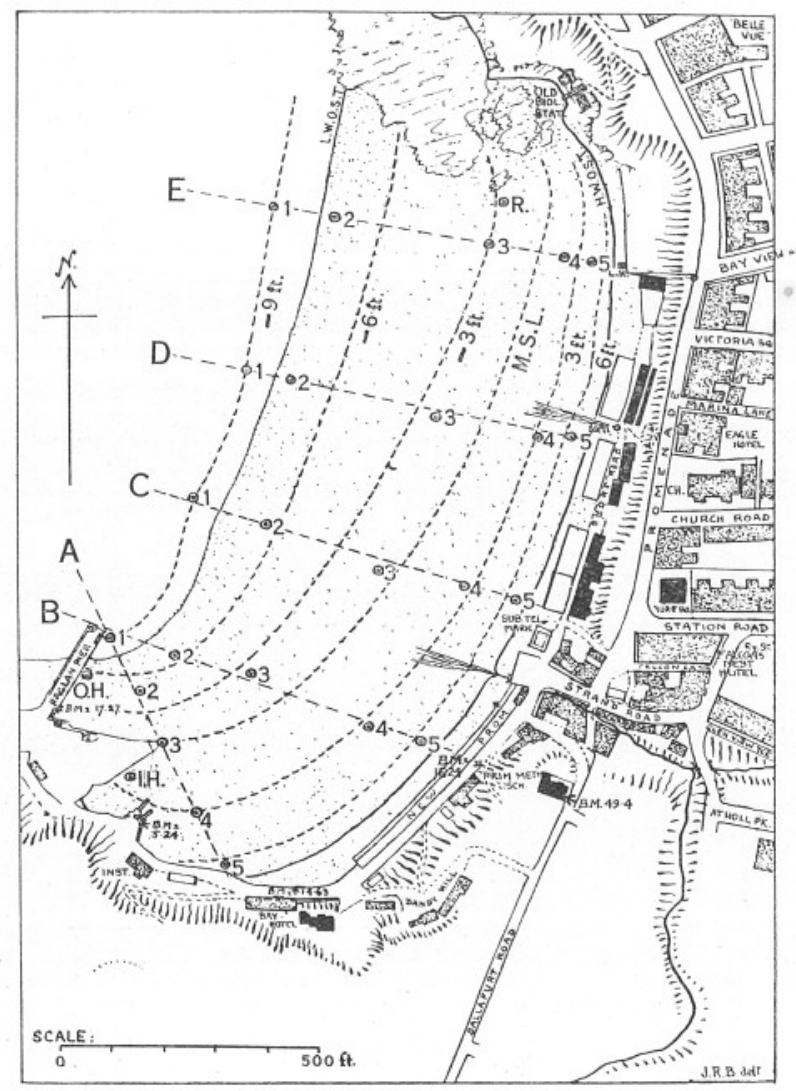

Fig. 1.--Plan of Port Erin Beach, showing Tid£l Contours and Sampling Stations.

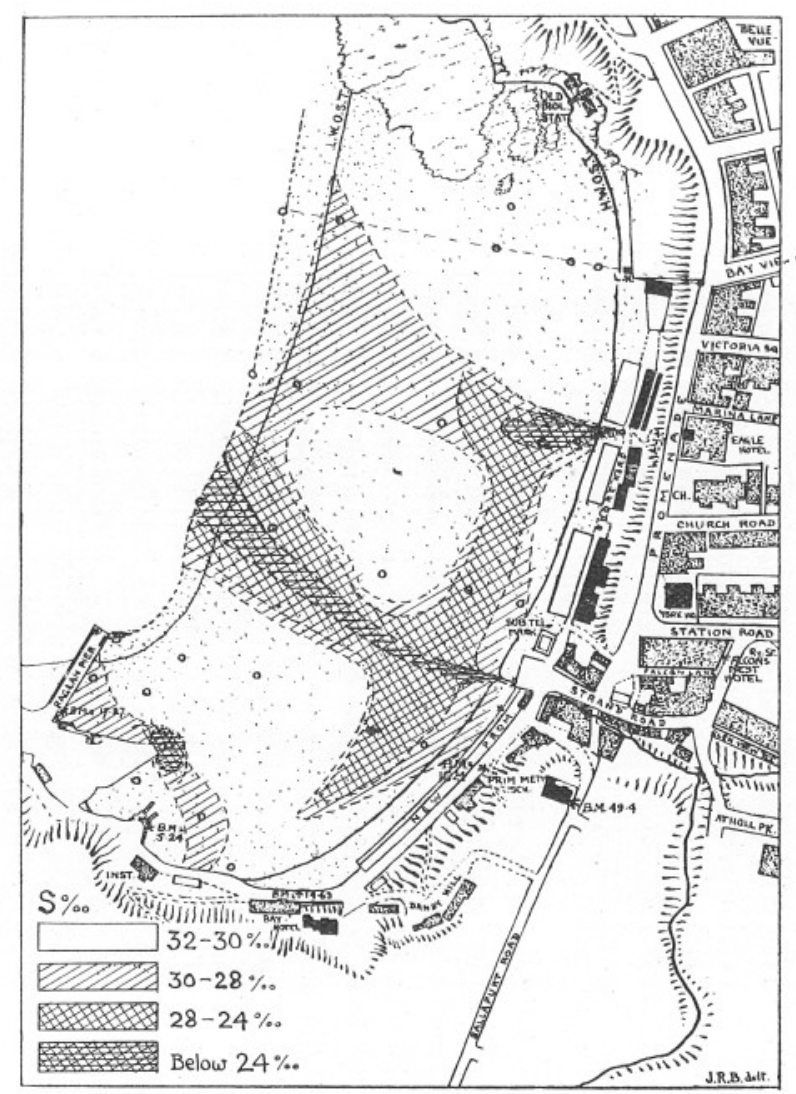

FIG. 2.-Isohalines of the Interstitial Water of the upper $20 \mathrm{~cm}$. of the Beach. 
It will be seen that the variations of $\mathrm{pH}$, as between the different stations, are quite small, and that there does not appear to be any significant relation with situation or other factors, except at Stations I.H. and $\mathrm{O} . \mathrm{H}$., where high values of $\mathrm{pH}$ are associated with fine grade, and the presence of sulphides, as attested by the blackness of the deposit. This association has been noted previously, at these Stations (Bruce, 3).

Salinity. The specific gravity of the water drained or filtered from the sand-sample, was determined by means of a small hydrometer, reading to 0.5 (water $=1000$ ). In view of the considerable sampling error, due to contamination of the sample with either sea-water or fresh drainagewater from the surface of the beach, it was felt to be unjustifiable to aim at a higher degree of accuracy than this. Using the hydrometer-reading, and the temperature of the water in the hydrometer-jar, the corresponding salinity-value (grammes total salts per 1000 grammes sea-water) was read from " Knudsen's Tables." The salinity of the sea, during the period (14th-23rd September, 1931) in which the beach observations were made, varied between $33.0 \%$ and $33.4 \%$, with a mean semi-diurnal value of $33 \cdot 16^{\circ}$ (Table 3 ). The results are of much interest, especially when, as in Figure 2, they are expressed in the form of salinity-contours, or " isohalines." In this figure, the data of Table 3 are coupled with observations on the ground as to the actual direction of the streams, etc., and the result conveys a fairly complete picture of the salinity conditions in the interstitial water of the upper $20 \mathrm{~cm}$. of the beach. The influence of the freshwater streams, spreading fanwise towards L.W.M., was, of course, to be

\section{TABLE 3.}

\section{Salinity of the Interstitial Water on the Sandy Beach at Port Erin-September.}

( $\mathrm{S}=$ grammes total salts per 1000 grammes sea-water.)

\begin{tabular}{|c|c|c|c|c|c|}
\hline Station & A & B & $\mathrm{C}$ & D & $\mathrm{E}$ \\
\hline 1. & \multicolumn{2}{|c|}{$31 \cdot 7$} & $23 \cdot 2$ & $30 \cdot 8$ & 30.8 \\
\hline 2. & 31.5 & $31 \cdot 0$ & $25 \cdot 8$ & $29 \cdot 1$ & $28 \cdot 4$ \\
\hline 3. & $23 \cdot 2$ & $31 \cdot 0$ & $30 \cdot 4$ & $29 \cdot 6$ & $30 \cdot 9$ \\
\hline 4. & 28.0 & $24 \cdot 0$ & $26 \cdot 7$ & $2 \cdot 7$ & $30 \cdot 6$ \\
\hline 5. & $30 \cdot 6$ & $29 \cdot 3$ & (dry) & (dry) & (dry) \\
\hline
\end{tabular}

expected, but the southerly extension of the low salinity areas above half-tide level, and the generally low salinity in the harbour area, introduce important factors into those areas of the beach, which are discussed, in their biological significance, on p. 292. 
Organic Matter. An attempt was made to determine the organicmatter content of the sands by various methods, including, of course, the standard procedure of "loss on ignition." Unsatisfactory results were obtained, due, in large measure, to the high calcium carbonate content of the material. Other methods, involving wet oxidation, were also tried, but found to be vitiated by the chloride which is always present in beach material. Under the circumstances, discussion of this important factor is deferred until a reliable method, now being sought, is available.

Mechanical Analysis. The material available from each Station for mechanical analysis consisted of

(a) the large amount of stones and gravel retained by the 2-mm. sieve, after the animals had been removed in the course of the biological examination of the material, and

(b) the much smaller amount, about $1 \mathrm{~kg}$., of unsieved and unsorted material, forming the residue from which the interstitial water, for chemical and other tests, had been filtered.

The proportions of coarse material in the several grades, 2-4 mm., 4-6 mm., and above $6 \mathrm{~mm}$., were determined by sieving the entire mass of the larger sample $(a)$ through a series of round-holed sieves, which were rotated in water, the amount retained by each being weighed wet, after draining and shaking out as much water as possible. By actual determination, the percentages of the several grades so obtained differed by less than one per cent from the values obtained by the usual but laborious procedure of weighing the original material dry, sieving in water, and again drying and weighing each fraction. The percentage of all material above $2 \mathrm{~mm}$. in the entire mass of sand and stones, at each station, was calculated on the assumed weight of the sample dug as $72.5 \mathrm{~kg}$. - that being the weight of a check sample taken under typical conditions. The mechanical analysis of the finer grades, up to $2 \mathrm{~mm}$., was carried out on the smaller sample $(b)$. This involved both sieving and elutriation. About $25 \mathrm{~g}$. of the undried material was sieved, in water, through the following series of round-holed sieves $-2 \mathrm{~mm} ., 1 \mathrm{~mm}$, $0.5 \mathrm{~mm}$. Material retained by the 2 -mm. sieve was rejected, as already included in the coarse-grade fractions above. The fractions retained by the $1-\mathrm{mm}$. and $0 \cdot 5-\mathrm{mm}$. sieves were transferred to tared filter-papers, dried, and weighed. The fraction passing $0.5 \mathrm{~mm}$. was transferred, in the wet state, to the separating vessel of a single tube elutriator, which was worked with fresh water, at $14^{\circ}-15^{\circ} \mathrm{C}$.

At first, a current of $6.7 \mathrm{~mm}$./sec. was applied; this carried over all material up to $0.1 \mathrm{~mm}$. diam., but the amount of this grade was negligibly small in every case, and it was disregarded in the subsequent calculations. 
The rate of flow was then increased to $25 \mathrm{~mm}$./sec., when the grade $0 \cdot 1-$ $0 \cdot 25 \mathrm{~mm}$. was carried over. This was collected, allowed to settle, decanted off, transferred to a filter-paper, dried and weighed, in the usual manner, the same process being applied to the residue in the elutriator, constituting the grade $0 \cdot 25-0.5 \mathrm{~mm}$. From the data so obtained, the percentage of each fraction in the total sand-grade (passing $2 \mathrm{~mm}$.) was calculated.

\section{TABLE 4.}

Mechanical Analyses of Sands from Port Erin Beach.

\begin{tabular}{|c|c|c|c|c|c|c|c|}
\hline \multirow[b]{2}{*}{ Station. } & \multirow[b]{2}{*}{$>\underset{\%}{>6 \mathrm{~mm}}}$. & \multirow{2}{*}{$\begin{array}{l}\text { Above } 2 \mathrm{~mm} \text {. } \\
\text { > } 4 \mathrm{~mm} \text {. } \\
\qquad \%\end{array}$} &. & \multirow{2}{*}{$\begin{array}{l}\text { Proportion of } \\
\text { coarse material } \\
\text { (all above } \\
2 \mathrm{~mm} .) \text { to total } \\
\text { coarse and fine. } \\
\%\end{array}$} & \multicolumn{3}{|c|}{$\multimap$ Below $2 \mathrm{~mm} . \longrightarrow$} \\
\hline & & & $>\underset{\%}{2 \mathrm{~mm}}$ & & $0 \cdot 5 \underset{\%}{2 \cdot 0-}$ & $\begin{array}{c}0 \cdot 5- \\
0 \cdot 25 \mathrm{~mm} \\
\%\end{array}$ & $\begin{array}{c}0 \cdot 25- \\
0 \cdot 1 \mathrm{~mm} . \\
\%\end{array}$ \\
\hline $\mathrm{Al}, \mathrm{Bl}$ & $54 \cdot 2$ & $22 \cdot 5$ & $23 \cdot 3$ & $0 \cdot 08$ & $0 \cdot 27$ & $7 \cdot 04$ & $92 \cdot 80$ \\
\hline A2 & $80 \cdot 2$ & $10 \cdot 9$ & $9 \cdot 1$ & $1 \cdot 10$ & $0 \cdot 56$ & $3 \cdot 36$ & $96 \cdot 29$ \\
\hline A3 & $72 \cdot 7$ & $9 \cdot 6$ & $17 \cdot 8$ & $0 \cdot 03$ & $0 \cdot 08$ & $6 \cdot 96$ & $93 \cdot 30$ \\
\hline A4 & $95 \cdot 0$ & $1 \cdot 7$ & $3 \cdot 3$ & $0 \cdot 04$ & $0 \cdot 11$ & $3 \cdot 75$ & $96 \cdot 30$ \\
\hline A5 & $62 \cdot 6$ & $11 \cdot 1$ & $26 \cdot 4$ & $0 \cdot 05$ & $0 \cdot 01$ & $8 \cdot 77$ & $91 \cdot 40$ \\
\hline B2 & $76 \cdot 9$ & $10 \cdot 7$ & $12 \cdot 5$ & $1 \cdot 13$ & $1 \cdot 82$ & $6 \cdot 38$ & $92 \cdot 01$ \\
\hline B3 & $87 \cdot 9$ & $6 \cdot 6$ & $5 \cdot 5$ & $2 \cdot 06$ & $1 \cdot 59$ & $10 \cdot 70$ & $87 \cdot 84$ \\
\hline B4 & $86-0$ & $7 \cdot 8$ & $6 \cdot 2$ & $1 \cdot 25$ & $0 \cdot 68$ & $24 \cdot 05$ & $75 \cdot 25$ \\
\hline B5 & $82 \cdot 8$ & $7 \cdot 7$ & $9 \cdot 6$ & $1 \cdot 10$ & 0.55 & 30.95 & $68 \cdot 60$ \\
\hline $\mathrm{Cl}$ & $71 \cdot 8$ & $18 \cdot 9$ & $9 \cdot 4$ & $1 \cdot 05$ & $2 \cdot 11$ & $1 \cdot 44$ & $96 \cdot 68$ \\
\hline $\mathrm{C} 2$ & $73 \cdot 7$ & $11 \cdot 5$ & $14 \cdot 8$ & $4 \cdot 70$ & $5 \cdot 18$ & $37 \cdot 50$ & $57 \cdot 30$ \\
\hline $\mathrm{C} 3$ & $73 \cdot 8$ & $12 \cdot 3$ & $13 \cdot 8$ & $7 \cdot 50$ & $11 \cdot 26$ & $43 \cdot 50$ & $45 \cdot 25$ \\
\hline $\mathrm{C} 4$ & $73 \cdot 8$ & $11 \cdot 8$ & $14 \cdot 6$ & $11 \cdot 20$ & $7 \cdot 73$ & $45 \cdot 80$ & $46 \cdot 40$ \\
\hline C5 & $89 \cdot 6$ & $5 \cdot 3$ & $5 \cdot 3$ & $40 \cdot 00$ & $11 \cdot 79$ & $55 \cdot 60$ & $32 \cdot 60$ \\
\hline D1 & $54 \cdot 7$ & $25 \cdot 1$ & $20 \cdot 3$ & $1 \cdot 29$ & $0 \cdot 36$ & $2 \cdot 60$ & $97 \cdot 21$ \\
\hline D2 & $67 \cdot 3$ & $17 \cdot 2$ & $15 \cdot 6$ & $1 \cdot 25$ & 0.93 & $2 \cdot 46$ & $96 \cdot 80$ \\
\hline D3 & $51 \cdot 1$ & $25 \cdot 5$ & $23 \cdot 4$ & $12 \cdot 30$ & $6 \cdot 83$ & $27 \cdot 60$ & $65 \cdot 70$ \\
\hline D4 & $47 \cdot 1$ & $21 \cdot 8$ & $31 \cdot 1$ & $23 \cdot 70$ & $22 \cdot 54$ & $34 \cdot 80$ & $42 \cdot 60$ \\
\hline D5 & $52 \cdot 1$ & $22 \cdot 2$ & $25 \cdot 7$ & $43 \cdot 70$ & $40 \cdot 22$ & $44 \cdot 50$ & $15 \cdot 40$ \\
\hline El & $46 \cdot 9$ & $17 \cdot 3$ & $35 \cdot 8$ & $0 \cdot 11$ & 0.62 & $6 \cdot 16$ & $93 \cdot 40$ \\
\hline E2 2 & $37 \cdot 2$ & $29 \cdot 1$ & $33 \cdot 7$ & $2 \cdot 70$ & $4 \cdot 57$ & 3.83 & $91 \cdot 79$ \\
\hline E3 & $56 \cdot 8$ & $19 \cdot 7$ & $23 \cdot 5$ & $5 \cdot 07$ & $2 \cdot 67$ & $10 \cdot 61$ & $86 \cdot 90$ \\
\hline E4 & $37 \cdot 6$ & $20 \cdot 3$ & $42 \cdot 2$ & $62 \cdot 70$ & $37 \cdot 84$ & $33 \cdot 95$ & $28 \cdot 15$ \\
\hline E5 & $40 \cdot 8$ & $26 \cdot 0$ & $33 \cdot 2$ & $50 \cdot 00$ & $40 \cdot 70$ & $32 \cdot 55$ & $26 \cdot 70$ \\
\hline I.H. & $44 \cdot 7$ & $19 \cdot 4$ & $36 \cdot 0$ & $0 \cdot 20$ & $0 \cdot 5$ & $1 \cdot 70$ & $97 \cdot 89$ \\
\hline O.H. & $52 \cdot 3$ & $21 \cdot 7$ & $26 \cdot 0$ & 0.50 & $0 \cdot 62$ & $1 \cdot 52$ & $98 \cdot 18$ \\
\hline R. & $41 \cdot 8$ & $26 \cdot 6$ & $31 \cdot 7$ & $1 \cdot 56$ & $2 \cdot 72$ & $5 \cdot 82$ & $91 \cdot 70$ \\
\hline
\end{tabular}

In this way, the grade-composition of the two classes of material, above and below $2 \mathrm{~mm}$. diam., are separately expressed, but related by an overall percentage (Table 4). A similar convention has been adopted, in the case of deep-water deposits, by Davis (4), who regards the materials above and below a certain limiting grade, which he places at $1.5 \mathrm{~mm}$. diam., as of differing biological significance. We believe the separation- 
limit at $2 \mathrm{~mm}$., as adopted in this paper, to be preferable on biological grounds, at least so far as the animals of the intertidal area are concerned. In addition, it permits of an uninterrupted sequence of comparison between the deposits of the intertidal beach and the true "soils" of the adjacent coasts, of which mechanical and other analyses, when available, are expressed on the $2-\mathrm{mm}$. basis, as accepted in agricultural practice. In Figure 3, an attempt is made to illustrate diagrammatically the grade-distribution on the beach, along the several transects. In the diagram, some slight liberties have been taken with the actual figures, in order to avoid confusion. The grades above $2-\mathrm{mm}$. diam. are treated as a whole, and amounts of these grades below $3 \%$ are disregarded, as adventitious.

\section{B. Biological.}

A preliminary investigation of the fauna of the sandy portion of Port Erin Bay was made by one of us (M. E. P.) in April, 1929, and this was continued and extended, in September, 1931, along quantitative lines. The nomenclature adopted corresponds, in general, with that of the new Plymouth Fauna List (6). The actual counts are those of the number of organisms per quarter square-metre, but in the Table of Occurrence the mean population per square-metre is given, together with the number of samples upon which the estimate is based. The results are quantitatively valid only for the season studied, and an extension of the survey to other times in the year would probably reveal some seasonal variation in frequency and distribution.

The results for all species found are given in the following Table, while in Figures $4-8$ an attempt is made to indicate diagrammatically the relative frequency of a few dominant species.

\section{Notes on the Species.}

Harmothoë lunulata (Delle Chiaje). A single specimen, at L.W. Springs, at Station A1, B1. Probably a migrant from its normal habitat, under stones and among Laminaria, on the seaward side of the pier.

Phyllodoce lineata (Claparède). Occurred in two samplings, at $\mathrm{Cl}$ and D1, in clean sand of fine grade, at extreme L.W.M.

Nereis diversicolor, O. F. Müller. Comparatively rare, found only at the Inner Harbour station.

Nephthys caca (O. F. Müller). (Fig. 4, p. 290.) A dominant type, all along the bay, except at the extreme south. Always appears to prefer clean sand, and to avoid the black sand, with its characteristic features of low oxygen-content, and presence of sulphides. Grade also appears to be an important factor in determining the distribution of this species, since it tends to extend to a higher tidal level where the sand is fine. 
Table of Occurrence of Species on the Sandy Beach at Port Erin, September, 1931.

(Mean number of specimens per square metre recorded at each Station.)

\begin{tabular}{|c|c|c|c|c|c|c|c|c|c|c|c|c|c|c|c|c|c|c|c|c|c|c|c|c|c|c|c|c|}
\hline Station & $\begin{array}{l}\mathrm{A} 1, \\
\mathrm{~B} 1\end{array}$ & A2 & A3 & A4 & A5 & $\begin{array}{l}\dagger \mathrm{A} 1, \\
\mathrm{~B} 1\end{array}$ & B2 & B3 & B4 & B5 & C1 & C2 & C3 & $\mathrm{C} 4$ & C5 & D1 & D2 & D3 & D4 & D5 & E1 & E2 & E3 & E4 & E5 & $\mathrm{R}$ & O.H. & T.H. \\
\hline No. of samples taken & 2 & 2 & 3 & 2 & 2 & 2 & 2 & 3 & 2 & 2 & 2 & 2 & 3 & 1 & 2 & 2 & 2 & 2 & 1 & 1 & 2 & 2 & 2 & 1 & 1 & 2 & 2 & 2 \\
\hline Harmothoë lunulata & 2 & $\cdots$ & $\cdots$ & $\cdots$ & $\cdots$ & 2 & $\cdots$ & $\cdots$ & $\cdots$ & $\cdots$ & $\cdots$ & $\cdots$ & $\cdots$ & . & $\cdots$ & & $\cdots$ & $\cdots$ & . & $\cdots$ & $\cdots$ & $\cdots$ & $\cdots$ & $\cdots$ & $\cdots$ & $\cdots$ & $\cdots$ & $\cdots$ \\
\hline Phyllodoce lineata & . & . & . & . & $\cdots$ & . & . & . & . & . & 2 & . & . & . & . & 2 & . & $\cdots$ & . & . & $\cdots$ & . & . & . & $\cdots$ & . & $\cdots$ & $\because$ \\
\hline Nereis diversicolor $\quad \ldots$ & . & $\cdots$ & $\cdots$ & . & . & $\cdots$ & 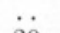 & . & $\cdots$ & . & $\cdots$ & $\cdots$ & $\therefore$ & . & $\cdots$ & $\therefore$ & $\cdots$ & . & $\cdots$ & . & . & $\cdots$ & . & $\cdots$ & $\cdots$ & & $\cdots$ & 2 \\
\hline Nephthys caeca (Fig. 4) .. & 2 & 2 & $\because$ & $\because$ & $\cdots$ & 2 & 20 & 16 & 2 & . & 8 & 8 & $1 \cdot 3$ & $\cdots$ & $\cdots$ & 12 & 8 & 2 & $\cdots$ & · & 14 & 2 & 4 & $\cdots$ & $\cdots$ & 16 & & 2 \\
\hline Nerine cirralulus (Fig. 5) & $\cdots$ & $\cdots$ & $1 \cdot 3$ & 2 & $\cdots$ & $\cdots$ & $\cdots$ & $1 \cdot 3$ & 10 & . & $\because$ & $\cdots$ & $1 \cdot 3$ & 4 & $\cdots$ & & & $\cdots$ & $\cdot$ & $\cdots$ & 2 & $\cdots$ & 6 & 4 & $\cdots$ & $\cdots$ & $\cdot$ & $\cdots$ \\
\hline Magelona papillicornis . . & & . & $\ddot{1} \ddot{3}$ & $\therefore$ & $\cdots$ & $\ddot{72}$ & $\cdots$ & . & 2 & . & 2 & 2 & $\cdots$ & . & $\cdots$ & 8 & 12 & $\cdots$ & $\cdots$ & $\cdots$ & 16 & $\because$ & $\cdots$ & $\cdots$ & $\cdots$ & $\cdots$ & $\because$ & . \\
\hline $\begin{array}{l}\text { Capitellids (young) } \\
\text { Arenicola marina (Fig. } 6 \text { ) }\end{array}$ & 16 & 12 & 12 & $\mathrm{i} 6$ & $\begin{array}{l}\cdots \\
\cdots\end{array}$ & $\begin{array}{l}72 \\
16\end{array}$ & $\ddot{2}$ & $\ddot{5 \cdot 2}$ & $\ddot{8}$ & $\begin{array}{l}\cdots \\
\cdots\end{array}$ & $\ddot{2}$ & $\ddot{2}$ & $\ddot{3}$ & $\begin{array}{l}\cdots \\
\cdots\end{array}$ & $\begin{array}{l}\cdots \\
\ldots\end{array}$ & $\ddot{4}$ & $\ddot{4}$ & $\ddot{12}$ & $\begin{array}{l}\cdots \\
\cdots\end{array}$ & $\begin{array}{l}\cdots \\
\cdots\end{array}$ & $\ddot{4}$ & $\ddot{12}$ & $\ddot{4}$ & $\begin{array}{l}\cdots \\
\cdots\end{array}$ & $\begin{array}{l}\cdots \\
\cdots\end{array}$ & $\dddot{6}$ & 10 & 10 \\
\hline Lanice conchilega & .. & . & . & . & . & . & 6 & .. & . & $\cdots$ & 2 & . & . & . & . & 2 & 2 & . & . & $\cdots$ & .. & . & . & . & $\cdots$ & . & . & . \\
\hline Eurydice pulchra (Fig. 7) & $\ldots$ & . & . & . & . & . & . & . & 64 & . & . & 2 & 20 & 32 & 2 & . & 2 & . & $\cdots$ & 4 & . & . & . & 4 & 4 & . & . & . \\
\hline Idotea sp. & . & . & . & . & . & . & . & . & .. & . & . & . & .. & . & . & . & . & . & * & . & . & . & . & . & $*$ & . & .. & . \\
\hline Bathyporeia sp. $\quad \ldots$ & . & $\cdots$ & $\cdots$ & $\cdots$ & . & . & . & $\therefore$ & $\because \dot{0}$ & . & . & $\cdots$ & $\cdots$ & . & $\cdots$ & . & . & & $\cdots$ & 4 & & $\cdots$ & $\cdots$ & $\cdots$ & . & $\dot{0}$ & . & $\cdots$ \\
\hline Urothoë marina (Fig. 8;... & . & . & . & . & . & . & . & $\therefore 8$ & 12 & . & . & . & 5 & . & . & & . & 2 & . & $\cdots$ & 2 & . & 4 & . & $\cdots$ & 2 & $\cdots$ & . \\
\hline Gammarus sp. $\quad$. & $\cdots$ & . & $\cdots$ & $\cdots$ & . & . & $\because$ & $1 \cdot 3$ & $\cdots$ & . & $\cdots$ & $\cdots$ & . & $\cdots$ & . & $\cdots$ & $\cdots$ & $\cdots$ & $\cdots$ & $\cdots$ & . & $\cdots$ & $\because$ & $\cdots$ & 4 & $\cdots$ & $\cdots$ & $\cdots$ \\
\hline Carcinus manas $\quad$. & . & $\cdots$ & $\cdots$ & $\cdots$ & $\cdots$ & $\cdots$ & 2 & . & $\cdots$ & $\cdots$ & $\cdots$ & $\cdots$ & $\cdots$ & $\cdots$ & $\cdots$ & $\because$ & $\because$ & $\cdots$ & $\cdots$ & $\cdots$ & $\cdots$ & $\cdots$ & 2 & $\cdots$ & $\cdots$ & $\cdots$ & $\cdots$ & $\cdots$ \\
\hline Echinocardium cordatum & $\cdots$ & $\cdots$ & . & $\cdots$ & $\cdots$ & . & 2 & . & $\cdots$ & $\cdots$ & ${ }_{0}^{2}$ & $\cdots$ & . & . & $\cdots$ & 2 & $\begin{array}{l}2 \\
0\end{array}$ & $\cdots$ & $\cdots$ & $\cdots$ & $\because$ & $\because$ & $\cdots$ & $\cdots$ & $\cdots$ & $\cdots$ & $\cdots$ & $\cdots$ \\
\hline Ammodytes tobianus $\quad$.. & & $\cdots$ & $\cdots$ & $\cdots$ & $\cdots$ & $\cdots$ & $\cdots$ & $\cdots$ & $\cdots$ & $\cdots$ & 2 & $\cdots$ & $\cdots$ & $\cdots$ & $\cdots$ & . & 2 & $\cdots$ & $\cdots$ & $\cdots$ & 4 & 2 & $\cdots$ & $\cdots$ & $\cdots$ & $\cdots$ & $\cdots$ & $\cdots$ \\
\hline
\end{tabular}

$\dagger$ The data from Station Al, B1 are re-inserted here to avoid apparent discontinuity of distribution.

* Present, but no count made. 
Nerine cirratulus (Delle Chiaje). (Fig. 5, p. 293.) A distinctly intertidal species, having its maximum density above Mean Sea Level. Grade appears to have little influence on its distribution.

Magelona papillicornis, Fr. Müller. Individuals are most numerous near L.W.M., and decrease in numbers towards the south end of the beach. Low salinity may be an inimical factor, although at this low level on the beach its-influence must be too transient to be of great importance.

Capitella sp. Young specimens of a Capitellid, probably C. capitata, were obtained in large numbers, just within the Raglan Pier at L.W.M. A few were also seen at A3 and in the Outer Harbour. The sand was black or grey at all these stations.

Arenicola marina, L. (Fig. 6, p. 293). A dominant species. Very numerous at all but the highest level on line A-this may be associated with the harbour conditions of fine grade and blackness of the sand beneath the surface. Arenicola marina is usually abundant in this type of habitat, and has been shown to be capable of withstanding low oxygen tension (Borden, 1).

Lanice conchilega (Pallas). In fine, clean sand, at and a little above L.W.M.

Eurydice pulchra, Leach (Fig. 7, p. 294). In large numbers, high up on the beach, near and above M.S.L., and in greatest abundance on lines $\mathrm{B}$ and $\mathrm{C}$. It was not recorded at all in the samplings taken in April, 1929. This is paralleled by observations at Millport (Elmhirst, 5), where the species is found, in winter, in shallow water below L.W. Springs, while in summer it is found further inshore.

Idotea sp. Young specimens, probably of $I$. neglecta, G. O. Sars, were found in considerable numbers in the sievings from D4 and E5, which were very stony, as well as in finer sand.

Bathyporeia sp. A single specimen, from D5, in a coarse stony sample.

Urothoë marina (Bate), (Fig. 8, p. 294). In fairly large numbers, particularly along line $\mathrm{B}$, which also showed the greatest population of Eurydice pulchra.

Gammarus sp. Occasional specimens, probably G. campylops, Leach, from B3 and E5.

Carcinus manas (Pennant). Only occasional specimens in the samples, although a relatively common shore form.

Echinocardium cordatum (Pennant). Only at extreme L.W.M., towards the southern end of the beach, but not actually within the harbour. It occurs where the sand is clean.

Ammodytes tobianus L. Occasional specimens, at L.W.M., towards the northern end of the beach, on lines C, D, and E. 


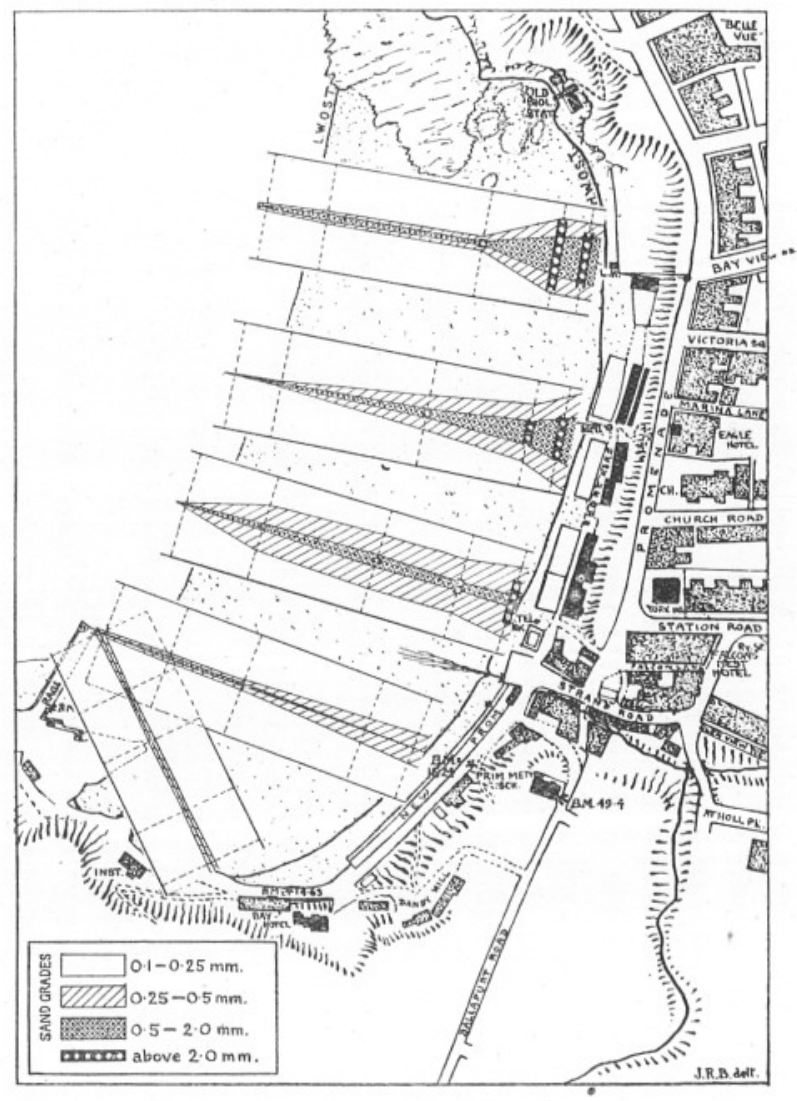

Fig. 3.-Composition of the Sand-grade, and Relative Amount of Stones and Gravel, in the upper $20 \mathrm{~cm}$. of Port Erin Beach. (The proportion of the successive fractions of the sand-grade (up to $2 \mathrm{~mm}$.) is denoted by the relative width of the shaded bands. The lengths of the superposed black bars are proportional to the percentage of coarse material (above $2 \mathrm{~mm}$.) in the entire mass.)

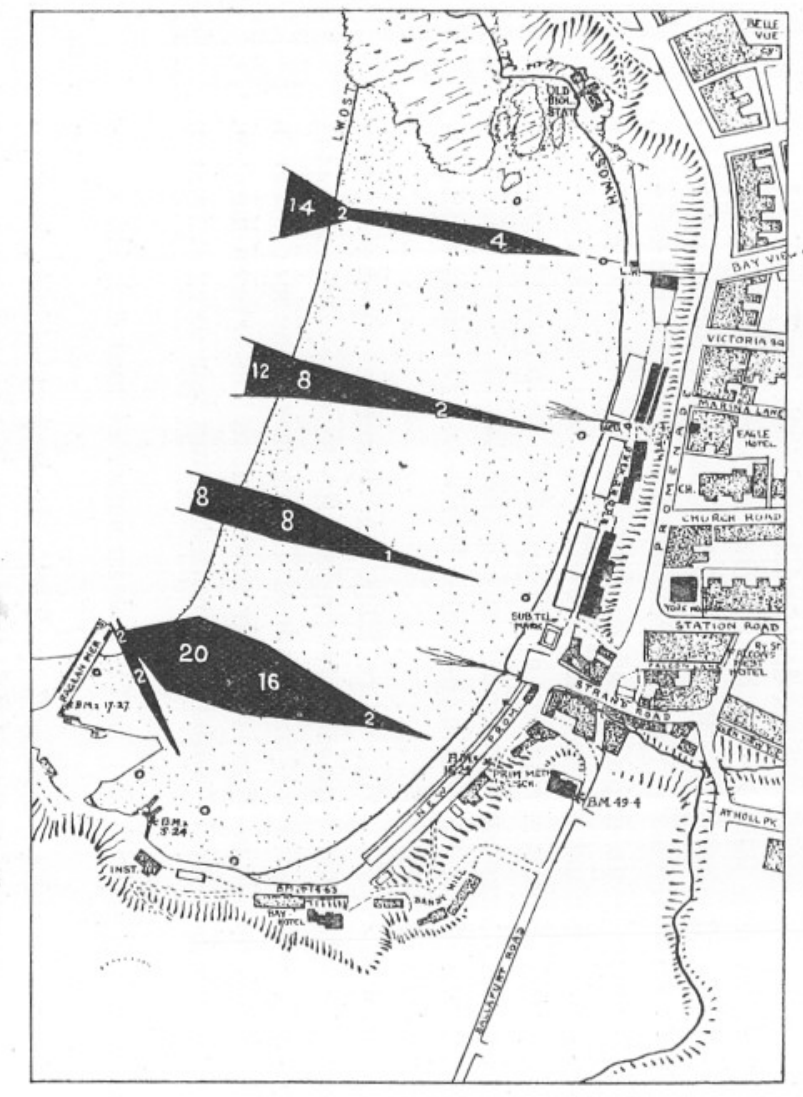

Fic, 4,-Distribution and Relative Freqnency of Nephthys cacca (O. F. Müller) on Port Erin Beach. The width of the bars is proportional to the density of population at each Station. 


\section{GENERAL REMARKS.}

It is clear that certain factors exert a paramount influence upon the observed faunal distribution in the area under survey-such are grade, tidal level, salinity, and exposure - and it is intended to restrict the discussion to these and their mutual relations.

\section{Grade.}

Regarded as an environmental factor, the grade-composition of a beachsand is of a very complex character. Not only may a sand consist of materials of widely varying grade, and of varying proportions of those grades, but the influence which it exerts upon its animal population may depend upon totally distinct mechanisms at different points in its range of variation. A case in point is that of a polychæte, which swallows the sand in which it lives, in order to extract nourishment from the associated organic matter. The amount and nature of the sand which the worm can swallow is clearly a factor which powerfully influences its distribution. There is a limiting size of particle, depending upon the capacity of the œsophagus, above which the material will be rejected as unsuitable. This larger material may, however, exert an influence in a different direction, since, if large enough, it will contribute greater stability to the deposit, or even afford beneficial shelter. Yet again, the presence of a large proportion of pebbles may render it difficult for the worm to burrow, although the grade of the deposit between the pebbles may be far below the ingestion limit.

\section{Tidal level.}

The effect of tidal level on the beach fauna is obviously one of great importance, since definite zones of distribution, more or less restricted to certain levels of the beach, are characteristic of a wide variety of species. The effect of such directly acting factors as exposure to air, light and heat, food supply, salinity changes, etc., can in most cases be studied experimentally, but in defining environmental conditions it is necessary to know not only the magnitude of the factors, but the period and duration of their incidence. For this reason it is of great importance to determine and record the exact level (in relation to mean sea level or other datum) of the point of observation. Where, as in the present survey, the levels have been accurately determined, the symmetry of the tide curve assumed (an assumption permissible under open coastal conditions), and the mean amplitude of the tide known, an exposure factor may be calculated for each station (Bruce, 2). If the distribution of definite species of animals on the shore is to be compared for various localities, sufficient data, as indicated above, must be given for the calculation of an exposure factor. 
At Port Erin, the tidal curve is practically a symmetrical one, and the range has a mean value of 15-16 feet.

At Port Erin two main zones may be recognised :-(1) a lower zone, extending from L.W.M. to M.S.L., in which Arenicola marina and Nephthys caca are dominant, with Magellona papillicornis, Echinocardium cordatum and Ammodytes tobianus in smaller numbers, and (2) an upper zone, from M.S.L. to H.W.M., where the dominant species are Eurydice pulchra, Urotheё marina, and Nerine cirratulus.

\section{Salinity.}

The influence of salinity upon the distribution of animals inhabiting the open waters of the sea is known to be great. While probably no less important in the inter-tidal region, the direct results of salinity changes are less evident, because obscured by the interaction of tidal and other factors. If, for example, the system of isohalines represented in Figure 2 were invariant, we should expect to find definite areas and zones of distribution of special forms, more or less corresponding with the salinity contours. On the contrary, no very close relationship can be traced. It must be remembered, however, that a salinity of $24 \%$ near the top of the beach will have a far greater influence, owing to the longer period of its action, between consecutive high waters, than the same salinity at L.W.M., where the condition will only obtain for a short time. The low value, for instance, at $\mathrm{C} 1$, was recorded at extreme low water of equinoctial springs, and might only be realised at that station for a few minutes on three or four days in the year. Under such circumstances, it could have no abiding influence upon distribution in general. Tidal level apart, salinity is subject to other and non-calculable influences - the fluctuations of rainfall affect the volume of the streams and the washing-out of salts from the beach, while wind and other factors bring about complete changes in the course of the streams across the beach even in a single season. No very close correlation, therefore, must be looked for, between the distribution of the fauna and the salinity of the beach, especially in the case of those forms in which a life-duration of several years tends to nullify short period influences.

\section{Exposure.}

Exposure is apparently the major factor in which the rich sandy beaches of the Clyde Area differ from that at Port Erin. No living molluses were taken in any of the samples during this survey, although Ensis siliqua and Lutraria lutraria occur, and the former was actually being speared by fishermen, at D1 and D2, at a depth below that of our sampling.

Cardium edule and Tellina tenuis are recorded as only occasionally 


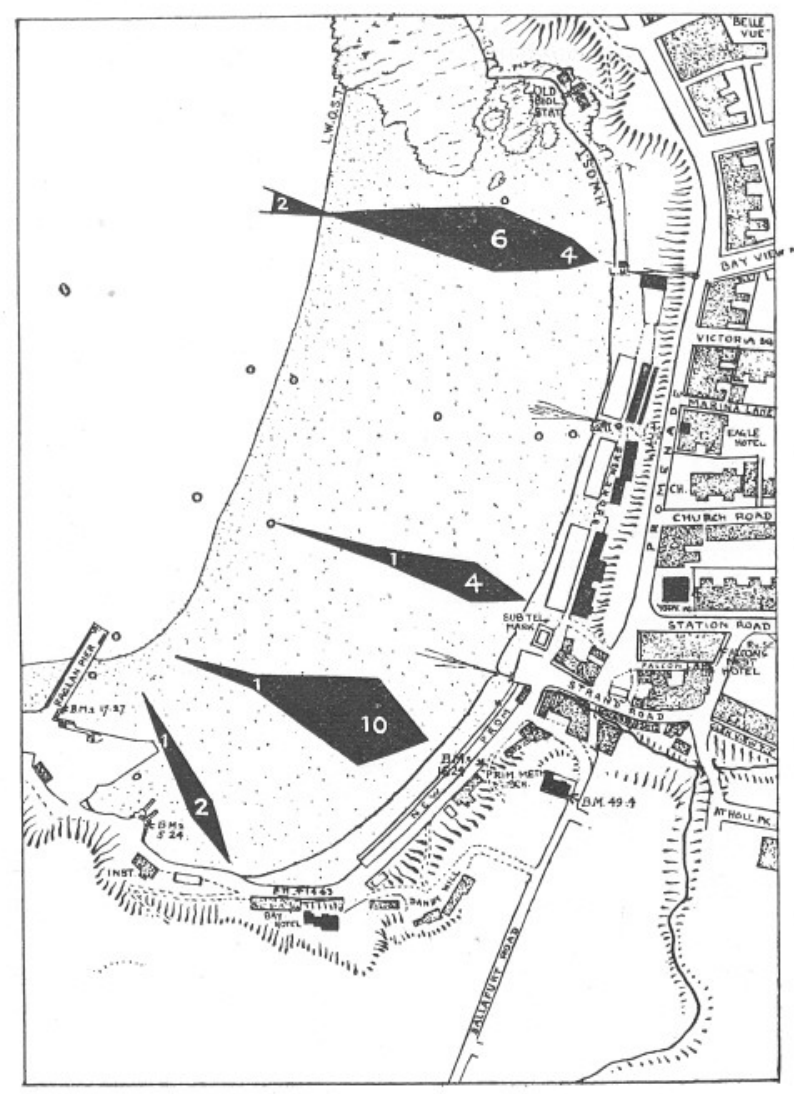

Fig. 5.-Distribution and Relative Frequency of Nerine cirratulus (Delle Chiaje) on Port Erin Beach.

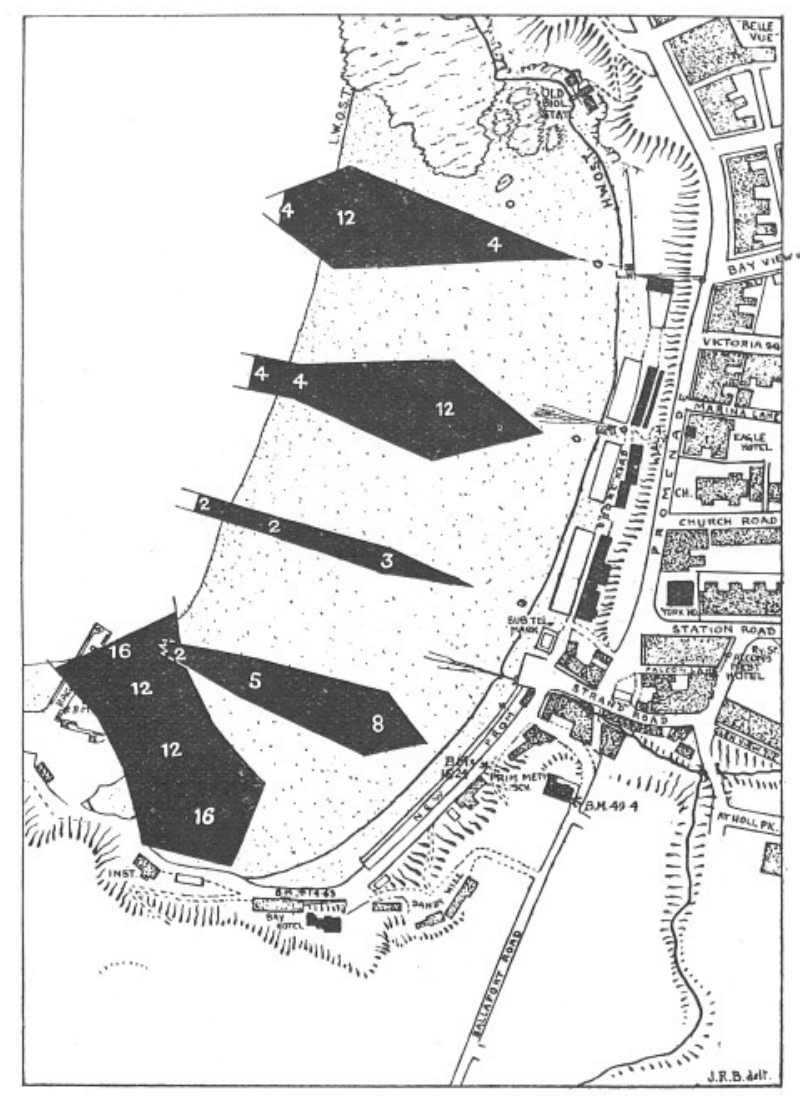

Fig. 6.-Distribution and Relative Frequency of Arenicola marina L. on Port Erin Beach. 


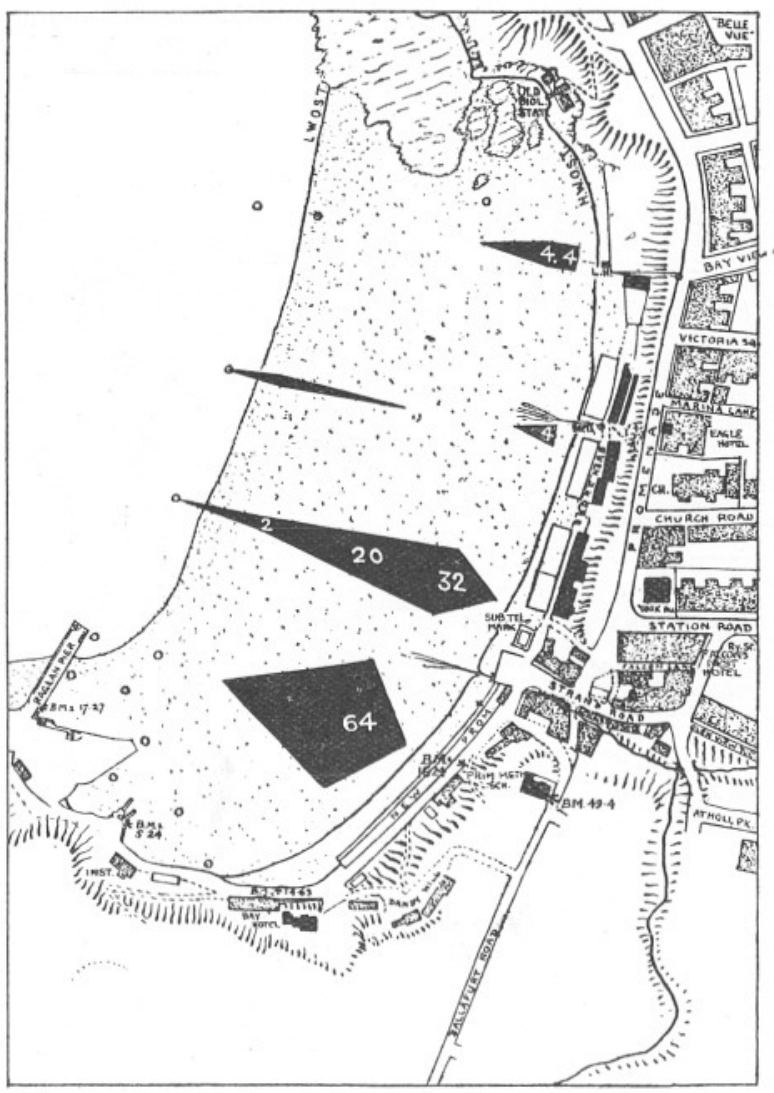

FIG. 7.-Distribution and Relative Frequency of Eurydice pulchra Leach on Port Erin Beach.

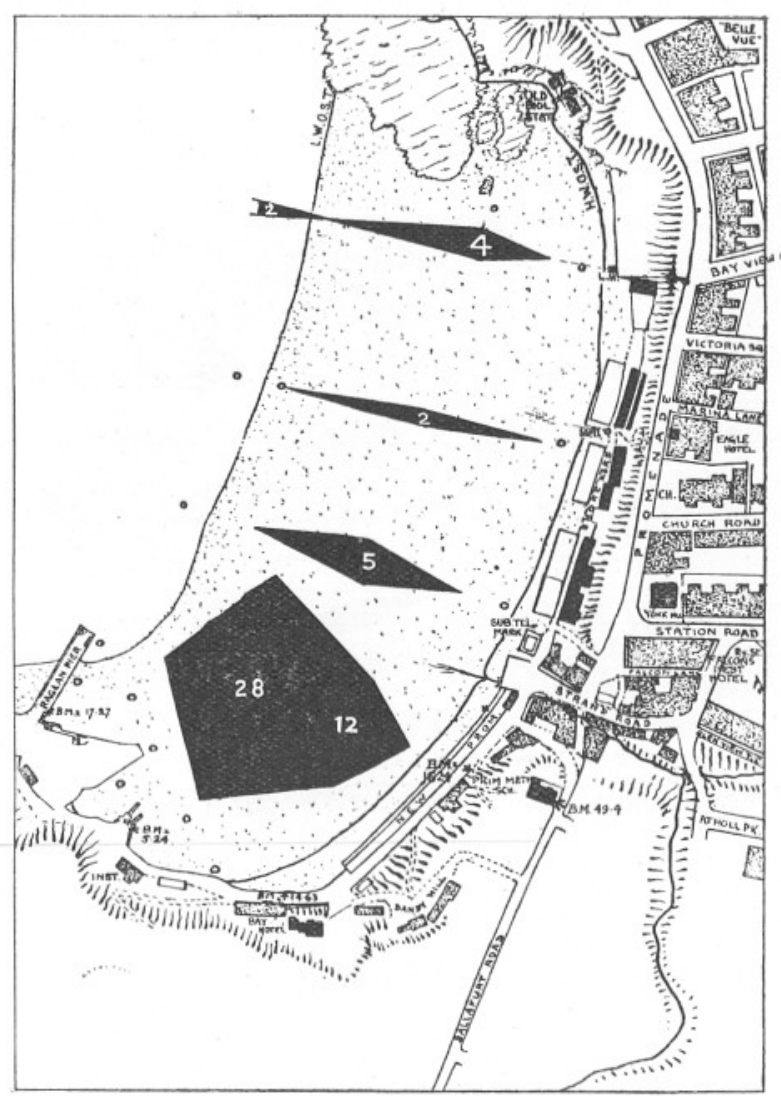

$\stackrel{0}{\dddot{0}}$

资

FIG. 8.-Distribution and Relative Frequency of Urothoë marina (Bate) on Port Erin Beach. 
present in the bay, below L.W.M., but it is of interest to record that numbers of fine large Cardium edule and Paphic pullastra are to be found in the gravel at the bottom of the sea-water baths in Port Erin Bay - in this situation they obtain much more shelter than on the open beach (Walton, 9).

Shelter from wave-shock is secured in the lee of boulders, rocks, and artificial harbour works. Almost invariably, there are concomitant factors of fine grade, high detritus-content, oxygen shortage, and blackness of the sand due to ferrous sulphide.

The authors desire to record their appreciation of much help afforded by their colleague Miss M. Parke, B.Sc., both during the shore-work and the subsequent compilation of this report.

\section{SUMMARY.}

A survey of the sandy beach at Port Erin, Isle of Man, was made in September, 1931. Observations were made, at a number of stations, involving simultaneous records of the macro-fauna and its density, and certain physical and chemical factors of the sand and interstitial water, as well as tidal level on the beach. The results enable certain general conclusions to be drawn as to the causes of the observed distribution of species, and of the differences between the faunas of this and some Scottish beaches. Plans are given, indicating tidal contours, salinity, and grade composition, in situ on the beach, together with frequency diagrams for five dominant species.

\section{REFERENCES.}

1. Borden, Mabel A. A Study of the Respiration and of the Function of Hæmoglobin in Planorbis corneus and Arenicola marina. Journ. Mar. Biol. Assoc., N.S., 17 (1931), pp. 709-738.

2. Bruce, J. R. Physical Factors on the Sandy Beach, Part I. Tidal, Climatic and Edaphic. Journ. Mar. Biol. Assoc., N.S., 15 (1928), pp. 535-552.

3. Bruce, J. R. Do., Part II. Chemical Changes. Journ. Mar. Biol. Assoc., N.S., 15 (1928), pp. 553-565.

4. Davis, F. M. Quantitative Studies on the Fauna of the Sea Bottom. No. 2. . . Southern North Sea Fish. Investig., Ser. ii, 8, No. 4 (1925).

5. Elmhirst, R. Studies in the Scottish Marine Fauna-The Crustacea of the Sandy and Muddy Areas of the Tidal Zone. Proc. Roy. Soc. Edin., 51, ii (1931), pp. 169-175. 
6. Marine Biological Association. Plymouth Marine Fauna, 2nd Ed., 1931.

7. Stephen, A. C. Notes on the Quantitative Distribution of Molluses and Polychætes in certain Intertidal Areas on the Scottish Coast. Proc. Roy. Phys. Soc. (Edin.), 21 (1928), pp. 205-216.

8. Stephen, A. C. Studies on the Scottish Marine Fauna: The Fauna of the Sandy and Muddy Areas of the Tidal Zone. Trans. Roy. Soc. Edin., 56 (1929), pp. 291-306.

9. Walton, C. L. A Contribution to the Ecology of some Cockle Beds. Trans. Liverpool Biol. Soc., 34 (1920), pp. 130-142. 